\title{
Analysis and Design of Microwave Dielectric Heating with Curved Plate Applicator for Deep Hyperthermia in Breast Cancer Treatment
}

\author{
Supawat KOTCHAPRADIT, Chanchai THONGSOPA, Thanaset THOSDEEKORAPHAT \\ School of Electronic Engineering, Suranaree University of Technology, \\ 111 University Avenue Muang, Nakhon Ratchasima 30000 Thailand \\ d5740253@g.sut.ac.th, chan@sut.ac.th, thanaset@sut.ac.th
}

Submitted April 29, 2019/ Accepted October 21, 2019

\begin{abstract}
This paper presents microwave hyperthermia treatment using dielectric heating techniques with the curved plate applicator. The $3 D$ breast phantom model simulation was used to investigate heat distribution. The microwave heating equation was employed to focus the power loss density in the deep breast phantom tissues that consists of skin, fat, and tumor, $2 D$ maximum $\left(W \cdot \mathrm{cm}^{-3}\right)$ are $5.67,11.92$, and 8.42 for tumor size as $10 \mathrm{~mm}, 16 \mathrm{~mm}$, and $30 \mathrm{~mm}$, respectively. The dielectric constant and loss factor of tumor tissue provides 55.25 and 19.8, respectively. The power loss density was analyzed and was excited by a microwave power signal generator $2450 \mathrm{MHz}$ inside of the breast phantom. This heating technique was implemented based on the electric field generated by the curved plate applicator, which is designed by a series resonance circuit with an LC matching element. Simulations revealed that the heating focused area could be targeted into the internal tumor. The measurement of dielectric properties at $24^{\circ} \mathrm{C}$ was performed by open-ended coaxial dielectric probe kit (N1501A, Keysight Technology) connected to a vector network analyzer (E5071C, Keysight Technology) that can be operated in the range of $1-10 \mathrm{GHz}$. The heat distribution was measured in agar phantom as a surrogate tumor tissue using IR cameras (U5857A True IR, Keysight Technology). The used parameters are microwave $D C$ input power of $120 \mathrm{~W}$, efficiency of about $20 \%$ and microwave power of $24 \mathrm{~W}$ to generate a stabilized temperature between $39^{\circ} \mathrm{C}$ and $42^{\circ} \mathrm{C}$.
\end{abstract}

\section{Keywords}

Dielectric applicator, microwave treatment, deep hyperthermia

\section{Introduction}

Currently, microwave hyperthermia is widespread in cancer treatment. The primary advantage of hyperthermia treatment is that it is non-invasive and minimizes pain and risk of infection. Microwave frequencies can have a focused effect on the tumor tissue site and heat the area efficiently. The primary purpose of hyperthermia is to increase the tumor temperature up to around $42-43^{\circ} \mathrm{C}$ for a sufficient time more than 30 to 60 minutes while keeping the surrounding tissues temperatures below $42^{\circ} \mathrm{C}$ [1], [2]. Commonly the technique uses antennas as a microwave applicator and to control the spread of the electromagnetic waves into tumor tissue to generate heat. The absorbed power loss density was calculated by the bio-heat transfer equation EM model [3-5].

The electromagnetic energy selectively heats the dielectric tumor tissue, which has properties that are significantly different than healthy tissues. Typically, this is performed in the range of (ISM) band $433 \mathrm{MHz}, 915 \mathrm{MHz}$, and $2450 \mathrm{MHz}$. Microwave energy absorption is better in tumors than in healthy tissues, particularly when induced from outside to the body or used for a short time. Nevertheless, the microwave frequency configuration is insufficient to deliver enough thermal energy to the tumor to be effective in treatment [6-15]. These studies indicate that microwave frequency at $2450 \mathrm{MHz}$ is suitable for clinical performance of tumor located less than $3 \mathrm{~cm}$ in tissues. Generally, the capacitive systems working at $70 \mathrm{MHz}$ exhibits significantly better penetration depth. This frequency is suitable to heat up tumors to a depth of $12 \mathrm{~cm}$ as given in the literature [16], [17], where the radiative superficial system operating at $2450 \mathrm{MHz}$ has an insufficient penetration. It is known that the dielectric behavior of tumor tissue at $70 \mathrm{MHz}$ is different from $2450 \mathrm{MHz}$. Furthermore, the capacitive heating of $70 \mathrm{MHz}$ should get the applied power level more than $300 \mathrm{~W}$ to generate a stabilized temperature between $39-42^{\circ} \mathrm{C}$ due to the conversion of the energy from the electromagnetic field into heat to tumor tissue and is suitable for large areas [18-20]. The advantages of $2450 \mathrm{MHz}$ applicator is employing less electric field power to heat up the tumor tissue in comparison to $70 \mathrm{MHz}$, considering the capacitive heating in lossy tissues as follows in (4). In this research, a capacitive system with microwave frequencies in conjunction with the curved plate applicator is proposed to improve the adequate heating and penetration 


\begin{tabular}{|c|c|c|c|c|c|c|}
\hline \multirow{3}{*}{ Material } & \multicolumn{4}{|c|}{ Electrical Property } & \multicolumn{2}{c|}{ Thermal Property } \\
\cline { 2 - 5 } & \multicolumn{3}{|c|}{$\begin{array}{c}\text { Conductivity } \\
\left(\sigma, \mathrm{Sm}^{-1}\right)\end{array}$} & \multirow{2}{*}{ Density $\left(\rho, \mathrm{kgm}^{-3}\right)$} & $\begin{array}{c}\text { Specific heat } \\
\left(C_{\mathrm{P}}, \mathrm{J} \mathrm{kg}^{-1} \mathrm{C}^{-1}\right)\end{array}$ \\
\cline { 2 - 7 } & $\begin{array}{c}\text { Dielectric } \\
\text { constant }\left(\varepsilon^{\prime}\right)\end{array}$ & Loss factor $\left(\varepsilon^{\prime \prime}\right)$ & Loss tangent $(\delta)$ & 0.69 & 1085 & 3770 \\
\hline Skin & 46.7 & 5.06 & 0.11 & 0.04 & 900 & 3500 \\
\hline $\begin{array}{c}\text { Breast } \\
\text { phantom }\end{array}$ & 5.60 & 0.29 & 0.05 & 0.13 & 1020 & 3500 \\
\hline Tumor & 4.44 & 0.95 & 0.21 & 0.80 & 1050 & 3500 \\
\hline
\end{tabular}

Tab. 1. Summary of material properties of skin, fat, breast phantom, and tumor at $2450 \mathrm{MHz}$.

depth. Especially, on the focal area of small tumors, it is necessary to avoid overheating of the applicator that affects the surrounding of the breast tissue.

There is a great deal of research proposing methods for effective control of the thermal conductivity. The studies of hyperthermia apparatus are focused on the electromagnetic energy on a focal region of the breast tissue and provide a means for protecting the nearby healthy tissues and for low power consumption. Tissue penetration by electromagnetic waves and using high frequency for direct thermal therapy within the breast tissue is a delicate matter. Studies on resonating metamaterial for microwave thermotherapy can improve the ability to dissipate heat into the tissues. The frequency dependence of reflection coefficients for the applicators are about $-18 \mathrm{~dB}$ [21-23]. Alternatively, dielectric heating offers an exciting new therapeutic avenue. Previous studies using sample tissues have found that breast cancer tissue has dielectric properties that respond to microwave frequencies. The material tested was made using a coaxial probe between $0.5-50 \mathrm{GHz}$ [24], [25]. The relative permittivity $\varepsilon_{\mathrm{r}}$ is divided into two parts, the real part of dielectric constant $\varepsilon^{\prime}$ and the imaginary part of loss factor $\varepsilon^{\prime \prime}$, which represents the frequency dependence. On average, the tumor tissue under test that is measured at $2450 \mathrm{MHz}$ in literature will have a loss factor of approximately 20 . From the microwave heating equation [26-28], dielectric loss factor $\varepsilon^{\prime \prime}$, and specific heat of the tissue is an important part that causes of heat, which indicates that the dielectric property that has a high loss factor $\varepsilon$ " value will be able to receive energy and convert it to thermal energy. Also, many studies show that microwave frequency affects the heat generated in the tissues by breast phantom [29-33]. The electrical and thermal properties mentioned above are listed in Tab. 1.

In this study, we present thermal treatment to tumor tissue using dielectric heating using a curved plate applicator. The curved plate applicator was designed using three-dimensional simulations and is based on the dielectric properties of the breast phantom at $2450 \mathrm{MHz}$. Similarly, the dielectric properties of the entire breast model, determined by measuring the agar phantom with openended coaxial probe kit (N1501A, Keysight Technology) between 1-10 GHz, are listed in Tab. 5. This property involves the efficiency of heating with the microwave power frequency source in $2450 \mathrm{MHz}$. In this experiment, the heat dissipation results are between $39-42^{\circ} \mathrm{C}$, as shown by thermal imaging by IR camera (U5857A True IR,
Keysight Technology). This demonstrates the ability to induce heat into the deep interior of the phantom model using the dielectric curved plate applicator technique.

In this work, the curve plate system will be modeled using a series resonance circuit and will be able to determine the frequency response capability. The matching network has been measured in 1 port by a vector network analyzer (E5071C, Keysight Technology). The LC element is designed to the input impedance of resonance circuit of $(50.3-\mathrm{j} 7.91) \Omega$, returns a loss matching $(-22.38 \mathrm{~dB})$ and $\operatorname{VSWR}(1.16: 1)$ at the frequency of $2400 \mathrm{MHz}$, bandwidth $163.5 \mathrm{MHz}$. This achieves a maximum power transfer into the dielectric loads. The microwave source has a DC input power of $120 \mathrm{~W}$, which with the efficiency of $20 \%$ should get microwave power of about $24 \mathrm{~W}$ $(43.6 \mathrm{dBm})$. The microwave power was measured by Bird (4391A, RF Power Analyst).

\section{Materials and Methods}

In this study, there were two sections, analytical 3D simulation, and experimentation. In the simulation, the curved plate applicator is done by the CST program to see the frequency response, power loss density, and E-field vector while there is a dielectric load inside. In terms of plate design, it is considered by the input impedance of the series resonance circuit, return loss (S11) and VSWR measurement using a vector network analyzer (E5071C, Keysight Technology). Therefore, this section describes the principles and design of a curved plate, which will demonstrate the results of the experiment in the form of power loss density and temperature distribution.

\subsection{Analytical Model of Curve Plates Applicator in the 3D Simulation Setup}

The analytical model of dielectric plate applicator in the 3D simulation was performed based on $2450 \mathrm{MHz}$. The curved plate was designed to increase the ability to focus on the electric field. The copper plates have a conductivity of $5.8 \times 10^{7} \mathrm{Sm}^{-1}$. During the simulation, we have determined the effectiveness of curved plate applicators to focus the heat absorption position for a tumor inside the breast phantom model. The properties of the dielectric material and tumor tissue were defined using the breast phantom model consisting of skin and fat. In the simulation, the 


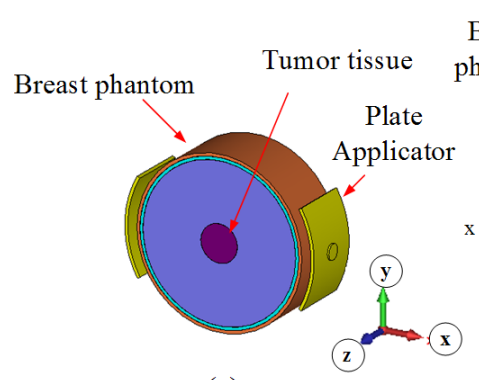

(a)

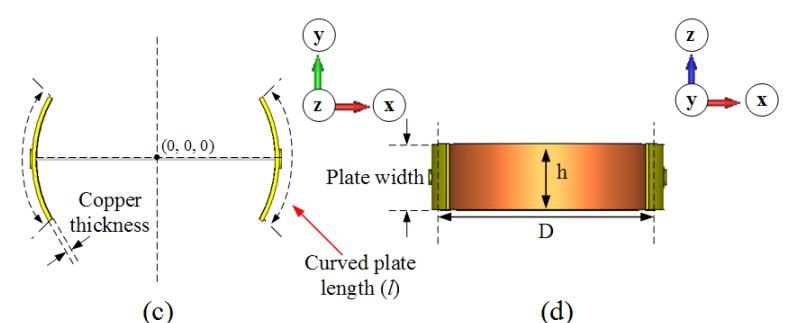

(c)

(d)

Fig. 1. The analytical model of dielectric material or breast phantom with tumor tissue in simulation: (a) curved plate applicator system, (b) breast phantom model, (c) curved plate with XY-plane orientation, and (d) curved plate with XZ-plane orientation.

tumor tissue is placed in a breast phantom model at the location $(0,0$, and $10 \mathrm{~mm})$ with diameter 10,16 , and $30 \mathrm{~mm}$. The dielectric properties including density $\left(\mathrm{kgm}^{-3}\right)$, relative permittivity $\left(\varepsilon_{\mathrm{r}}\right)$, and electric conductivity $\left(\sigma, \mathrm{Sm}^{-1}\right)$ of various tissues are provided in Tab. 1 . Subsequently, the effect of the electric field is analyzed in the study. For analyses of the focusing of the electric field materials, we specify an impedance of $50 \Omega$ for the frequency source. In Fig. 1 the dimensions and schematic details of the curved plate applicator for analyzing the electric field focusing are shown. The curved plates size includes plates length $(l$, $60 \mathrm{~mm})$, copper thickness $(1 \mathrm{~mm})$, plates width $(20 \mathrm{~mm})$, breast phantom width $(D, 50 \mathrm{~mm})$ and height $(h, 25 \mathrm{~mm})$, respectively.

\subsection{Concept and Construction of Curved Plate Applicator for Dielectric Heating}

In this section, the design of the curved plate applicator was performed by a series resonance circuit model, as shown in Fig. 2. The curved plate applicator works with a series resonance circuit that uses an LC matching element $\left(X_{\mathrm{L}}=+\mathrm{j} \omega L, X_{\mathrm{C}}=-1 /(\mathrm{j} \omega \mathrm{C})\right)$. The plate itself acts as a capacitor in the series resonance circuit. In design, the relative permittivity value of about 4.44 is used for calculating the capacitance between the two plates by estimating from a parallel plate equation standard using $C=K E_{0}(A / D)$, where $E_{0}=8.854 \times 10^{-12} \mathrm{~F} / \mathrm{m}, K$ is the dielectric constant, $A$ is the surface area of the plate $\left(\mathrm{m}^{2}\right), D$ is the distance between the plate $(\mathrm{m})$ and $C$ is the capacitance $(\mathrm{F})$. To calculate the LC element value, use the resonance frequency equation as follows

$$
f=\frac{1}{2 \pi \sqrt{L C}} .
$$

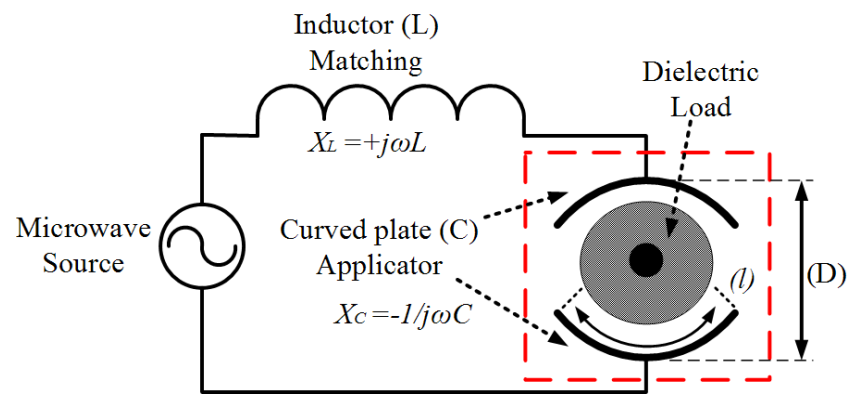

Fig. 2. Schematic of series resonance circuits consisting of the curved plate applicator and L matching element.

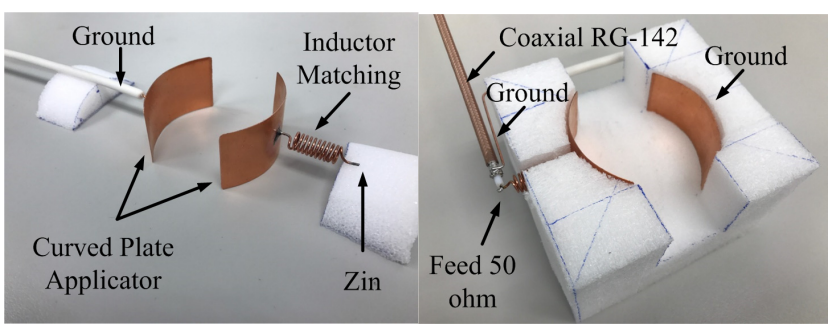

Fig. 3. Construction of the curved plate applicator.

When $X_{\mathrm{L}}=X_{\mathrm{C}}$ the maximum power transfer is reached. For the used resonance frequency at $2450 \mathrm{MHz}$, $L=168 \mathrm{nH}$, and $C=0.025 \mathrm{pF}$ were used in this calculation.

Figure 3 shows the curved plates designed for the series of experiments. The plates have the following specifications: length of the curved plate $l=\lambda / 2=6 \mathrm{~cm}$, plate width is $3 \mathrm{~cm}$, and radius $D / 2=2.5 \mathrm{~cm}$. The plate has a curvature of angle $\theta=60^{\circ}$. The material used as the base for the curved plate plan has the dielectric properties close to the air $\left(\varepsilon_{\mathrm{r}}=1\right)$.

\section{Analysis and Temperature Distribu- tion}

The power loss density was investigated in the form of heat distributions in the 3D model. The increasing temperature of the dielectric material was the result of absorbed microwave energy due to the loss factor of the tumor tissue and the highest resonance frequency obtained with the curved applicator. Consequently, the power loss density is observed by simulation and 2D cross-section of breast phantom. The temperature changes are dependent on the strength of the electric field from the microwave power oscillator into the applicator systems and the duration of the treatment period. The temperature distribution in the dielectric loss tissues can be calculated from the electric field power and dielectric loss factor. Moreover, we controlled the heating temperature as a function of the applicator systems. The bio-heat transfer equation can be solved for the temperature distribution in loss media by assuming the loss media is a replica of human tissues or breast. It can be expressed as follows [3], [23], [26-28]: 


$$
\begin{gathered}
\frac{\partial T}{\partial t}=R_{T} \nabla^{2} T+\alpha P, \\
R_{T}=\frac{k_{t}}{\rho C_{P}}
\end{gathered}
$$

where $T$ is the temperature $\left({ }^{\circ} \mathrm{C}\right), t$ is the heating time period (s), $R_{\mathrm{T}}$ is the distribution temperature $\left(\mathrm{m}^{2} \mathrm{~s}^{-1}\right), k_{\mathrm{t}}$ is the thermal conductivity of tissue $\left(\mathrm{W} \cdot \mathrm{cm}^{-1}{ }^{\circ} \mathrm{C}^{-1}\right), \rho$ is the local physical density of tissue $\left(\mathrm{kgm}^{-3}\right), C_{\mathrm{P}}$ is the specific heat capacity of an object $\left(\mathrm{J} \cdot \mathrm{kg}^{-1}{ }^{\circ} \mathrm{C}^{-1}\right), \alpha$ is the correction coefficient $\left(\alpha=1 /\left(\rho C_{\mathrm{P}}\right)\right)$, and $P$ is the power loss density $\left(\mathrm{W} \cdot \mathrm{cm}^{-3}\right)$ :

$$
P=5.536 \times 10^{-11} f E^{2} \varepsilon^{\prime \prime} .
$$

The power loss density was calculated from dielectric loss factor $\left(\varepsilon^{\prime \prime}\right), E$ is the electric field $\mathrm{V} \cdot \mathrm{cm}^{-1}$, and $f$ is the frequency $(\mathrm{Hz})$. The simulated and experimental models of dielectric heating were conducted by analyzing the power loss density of the plate applicator. It will be described in more detail in the next section.

\section{Numerical Results}

We investigated the power loss density, which can be controlled by the shape of the curved plates and varying a dielectric gap. Moreover, the studies show that the position of the treatment region could be directed inside the curved plates over the dielectric load. Full-wave 3D numerical simulation was performed using the dielectric heating method to verify the field distribution on the model. The curved plate applicator has been measured to optimize the operating frequency response. They are optimizing parameters such as return loss, VSWR, and impedance of system analyzed in the series resonance circuit. The dielectric properties in the experiments were measured to determine the efficacy of the microwave heating.

\subsection{Evaluation of Electric Loss Density}

The power loss density $\left(\mathrm{W} \cdot \mathrm{cm}^{-3}\right)$ distributions of the heating in the tumor treatment using curved plate applicator was examined in Fig. 4. The simulation results showed that heating efficiency was related to the tumor size. The maximum heat occurred between electrode plates, and power loss density was dependent on the size of tumor tissue inside. Furthermore, the result of the curved plate also functioned in reducing heat distribution in healthy tissues of breast phantom, but midpoint heating increased. In the simulation, the investigation results uncovered $2 \mathrm{D}$ maximum power loss density of $5.67 \mathrm{~W} \cdot \mathrm{cm}^{-3}$ for tumor size of $10 \mathrm{~mm}$. As mentioned, the diameter of the tumor changed to be $16 \mathrm{~mm}$ and $30 \mathrm{~mm}$, the distributions of the power absorption per volume also changed to $11.92 \mathrm{~W} \cdot \mathrm{cm}^{-3}$, and $8.42 \mathrm{~W} \cdot \mathrm{cm}^{-3}$ in logarithmic scale respectively. Unequal absorption power for each tumor size was found in the investigation result. In this simulation, the dielectric model consists of skin, fat, breast phantoms, and tumor tissue whose dielectric constants $\left(\varepsilon^{\prime}\right)$ are 46.7, 5.6, 4.44 , and 55.25 , respectively. The loss factor $\left(\varepsilon^{\prime \prime}\right)$ of the tumor is 19.8 , the tumor was located at $(0,0$, and $10 \mathrm{~mm})$. The diameter size of the breast phantom is $50 \mathrm{~mm}$. It seemed that power loss density of surrounding tissues inside applicator was not very high compared to the centered tumor. The heat distribution in ${ }^{\circ} \mathrm{C} \cdot \mathrm{s}^{-1}$ of (2), was established from the power loss density $\left(\mathrm{W} \cdot \mathrm{cm}^{-3}\right)$ and dielectric loss factor $\left(\varepsilon^{\prime \prime}\right)$ mentioned above into the last term of (4). The value of power loss density, which was more than $5 \mathrm{~W} \cdot \mathrm{cm}^{-3}$ to heat up tumor tissue to $39-43^{\circ} \mathrm{C}$ is depending on periods. Also, the temperature was investigated in the next section. The treatment simulation may require the idealized input power port to heat the tumor tissue to the desired one. The power loss density of analytical model was shown in Fig. 4.

Similarly, in Fig. 5 the orientation of the E-field vector (phase 0 deg.) mostly is diverted into the internal core of the breast phantom. The ability of the curved plate

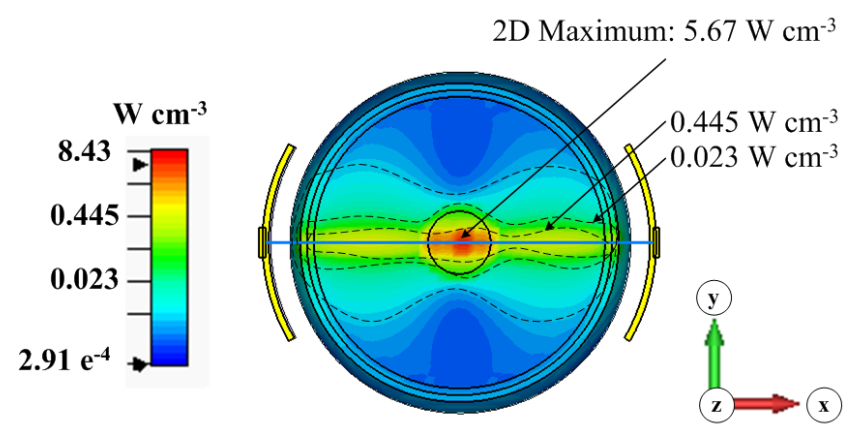

(a)

2D Maximum: $11.92 \mathrm{~W} \mathrm{~cm}^{-3}$
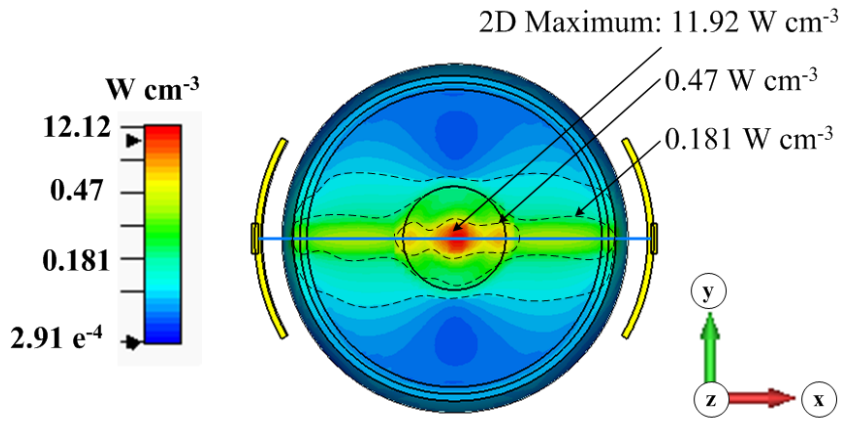

(b)

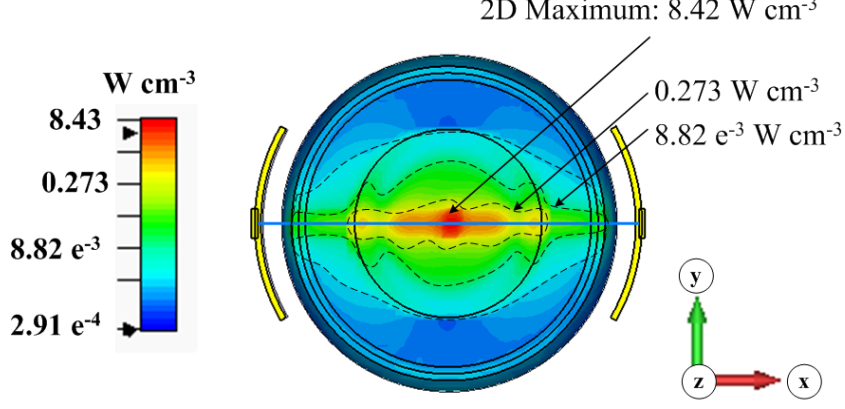

(c)

Fig. 4. Power loss density of the breast tumor heating model with tumor size (a) $10 \mathrm{~mm}$, (b) $16 \mathrm{~mm}$ and (c) $30 \mathrm{~mm}$. 
to focus an E-field vector to the internal core is possible. The investigation of E-field intensity is $45.43 \mathrm{~V} \cdot \mathrm{cm}^{-1}$, $64.74 \mathrm{~V} \cdot \mathrm{cm}^{-1}$, and $54.02 \mathrm{~V} \cdot \mathrm{cm}^{-1}$ in linear scale for tumor size $10 \mathrm{~mm}, 16 \mathrm{~mm}$ and $30 \mathrm{~mm}$ respectively. The tumor has higher power absorption because the dielectric loss factor $\left(\varepsilon^{\prime \prime}\right)$ responding to $2450 \mathrm{MHz}$ in tumor tissue is more significant than in the surrounding tissues given in Tab. 1. Although the orientation of the E-field vector, which is perpendicular to the fat tissue interface with low permittivity. The tumor tissue has a higher permittivity in an electric field that is integrated; the ability to store electrical energy into the core is high. For this reason, there is a high penetration of depth, under the applicator that is an electric field. Also, evidence suggests that the microwave can pass through the dielectric material with high loss factor $\left(\varepsilon^{\prime \prime}\right)$, is that the return loss (S11) is lower than $-10 \mathrm{~dB}$, as shown in Fig. 6. From the analysis, the density of tumor tissue in each size also affects the direction of the E-field vector.

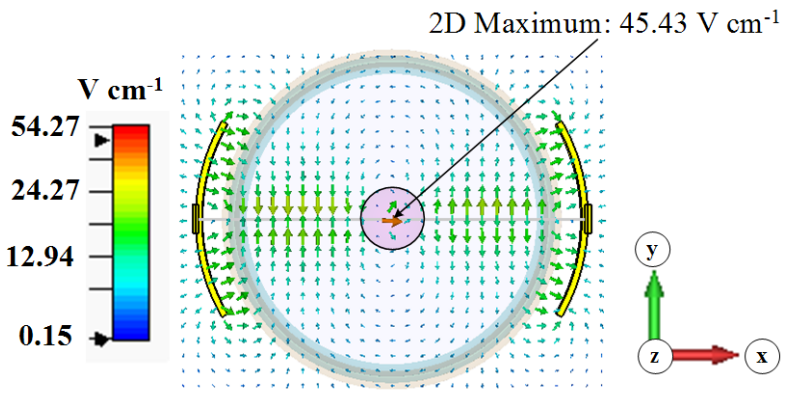

(a)

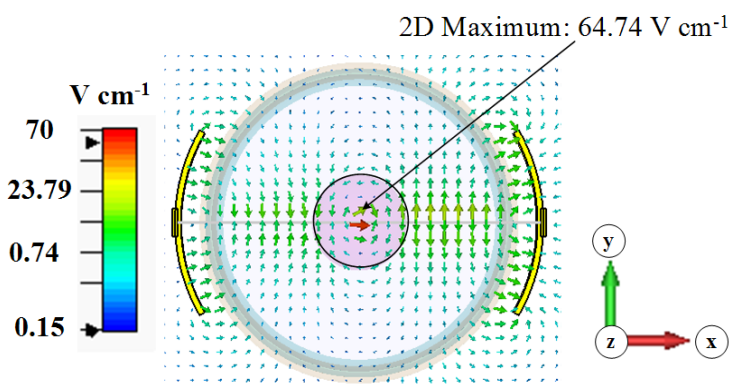

(b)

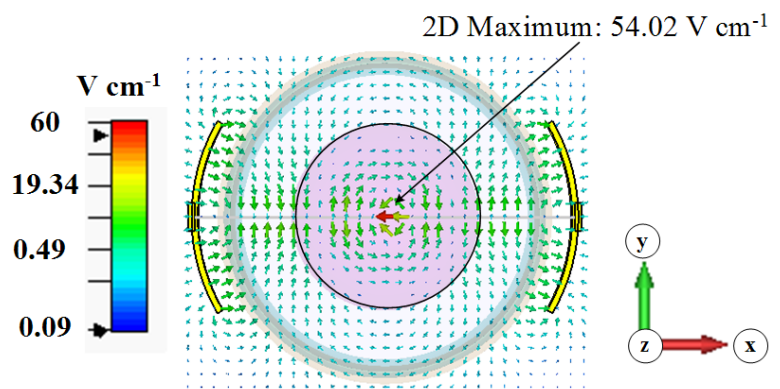

(c)

Fig. 5. E-field vector of the curved plate with tumor size (a) $10 \mathrm{~mm}$, (b) $16 \mathrm{~mm}$ and (c) $30 \mathrm{~mm}$.

\subsection{Simulation and Measured the Frequency Response of Curved Plate Applicator}

The efficiency of the curved plates, inside the Agar phantom, yields the dielectric loss factor $\left(\varepsilon^{\prime \prime}\right)$. In the simulation, the dielectric material has the dielectric loss factor of breast phantom and tumor tissue by 0.95 and 19.8 , respectively. The tumor tissue located at $(0,0$, and $10 \mathrm{~mm})$, fat and skin have the dielectric losses factor by 0.29 and 5.06, respectively. Upon changing the tumor diameter size to $10 \mathrm{~mm}, 16 \mathrm{~mm}$, and $30 \mathrm{~mm}$, the simulation results of each diameter size are $-10.97 \mathrm{~dB}$ at $2.528 \mathrm{GHz},-18.19 \mathrm{~dB}$ at $2.438 \mathrm{GHz}$, and $-12.48 \mathrm{~dB}$ at $2.398 \mathrm{GHz}$, respectively. This relationship is illustrated in Fig. 6. The simulation results of the return loss of each tumor size are not equal and are depending on each intrinsic resonance frequency. Similarly, the reflection value is displayed in term of VSWR, as shown in Fig. 7. In simulation results, VSWR will respond to the size of the tumor tissue at the same frequency as return loss. The VSWR will have values of $1.78,1.28$, and 1.62 , respectively. The maximum values of each tumor size across these differing conditions are summarized in Tab. 2.

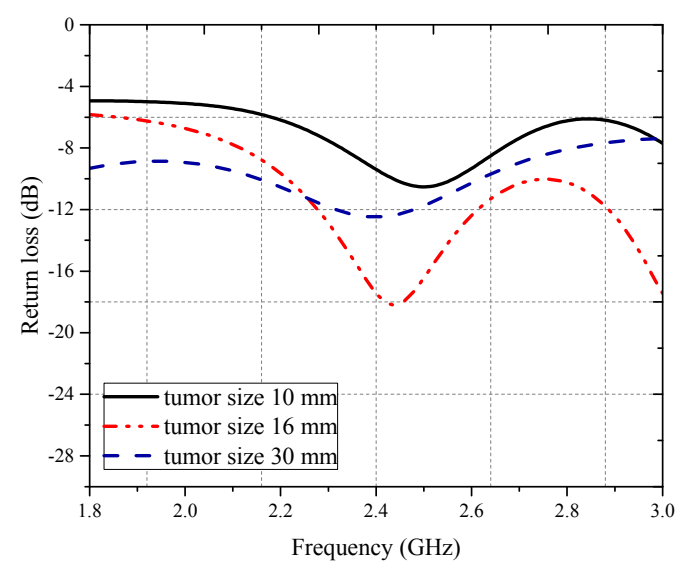

Fig. 6. Return loss in $\mathrm{dB}(\mathrm{S} 11)$ of series resonance circuit in simulation with tumor size $10 \mathrm{~mm}, 16 \mathrm{~mm}$, and $30 \mathrm{~mm}$.

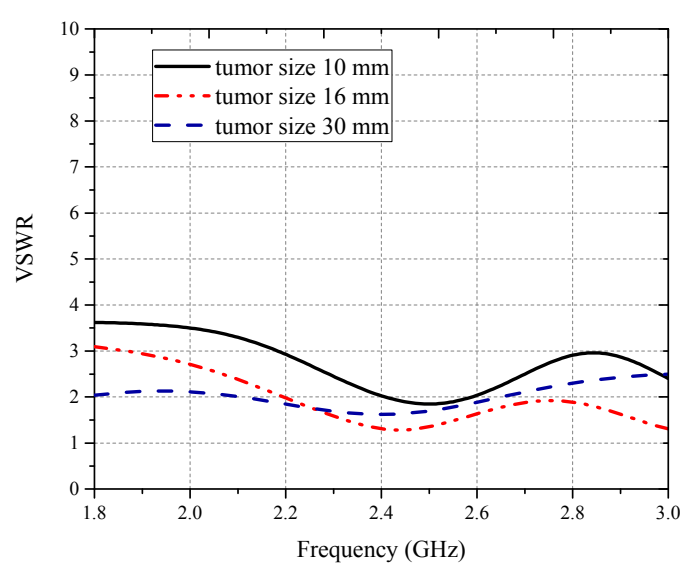

Fig. 7. VSWR of series resonance circuit in simulation with tumor size $10 \mathrm{~mm}, 16 \mathrm{~mm}$, and $30 \mathrm{~mm}$. 


\begin{tabular}{|c|c|c|c|}
\hline $\begin{array}{c}\text { Tumor } \\
\text { size }(\mathrm{mm})\end{array}$ & $\begin{array}{c}\text { Resonance } \\
\text { frequency }(\mathrm{GHz})\end{array}$ & Return loss $(\mathrm{dB})$ & VSWR \\
\hline 10 & 2.52 & -10.97 & 1.78 \\
\hline 16 & 2.43 & -18.19 & 1.28 \\
\hline 30 & 2.39 & -12.48 & 1.62 \\
\hline
\end{tabular}

Tab. 2. Return loss and VSWR of the series resonance circuit in simulation for each maximum frequency with tumor tissue size $10 \mathrm{~mm}, 16 \mathrm{~mm}$, and $30 \mathrm{~mm}$.

Table 2 shows the comparison of the frequency response $(-18.19 \mathrm{~dB})$ of the tumor while in conjunction with the curved plate. As a result, varying the simulated tumor size, it was found that the size of the tumor that responded to the frequency of $2450 \mathrm{MHz}$ was $16 \mathrm{~mm}$. This achieves a maximum power transfer into tumor tissue.

The signal measurement test experimental setup is shown in Fig. 8. The frequency response of the curved plate applicator has been measured using a vector network analyzer (E5071C, Keysight Technology) using the curved plate and inductor input impedance and sweep frequency in the series resonance circuit. The frequency response of the curved plate applicator includes return loss (S11), voltage standing wave ratio (VSWR) and impedance $(R+\mathrm{j} X)$ on the Smith chart, determining the measurement range from 1.8 to $3 \mathrm{GHz}$. The design considers the properties of the series resonance circuit with the LC matching network consisting of an inductor (L) and capacitor (C) that acts as the curved plate applicator. The variable that affects the frequency response is the dielectric properties of the breast phantom and tumor tissue, which in turn affect the capacitance in the resonance circuit and act as a load to absorb the microwave energy.

The next experiment compared the simulation for $16 \mathrm{~mm}$ tumor size, which is the range with the maximum frequency response relative to $2450 \mathrm{MHz}$ and VSWR. The return loss of the series resonance circuit for the LC network was measured using a vector network analyzer (E5071C, Keysight Technology). Figure 9 plots the relationship between frequency and measured return loss (S11). As shown, for a measured return loss less than $-10 \mathrm{~dB}$ and the bandwidth for curved plate applicator of $163.5 \mathrm{MHz}$ will cover a frequency range between $2.31 \mathrm{GHz}$ and $2.48 \mathrm{GHz}$ and will respond to $2.41 \mathrm{GHz}$ at

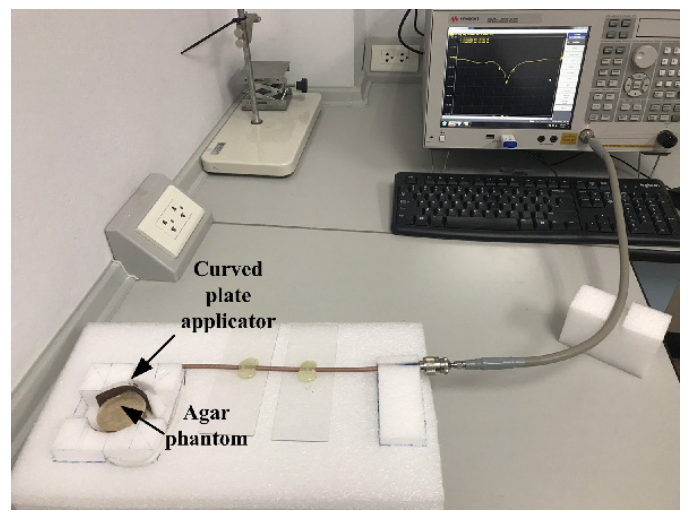

Fig. 8. Measurement setup for curved plate applicator designed with the agar phantom.

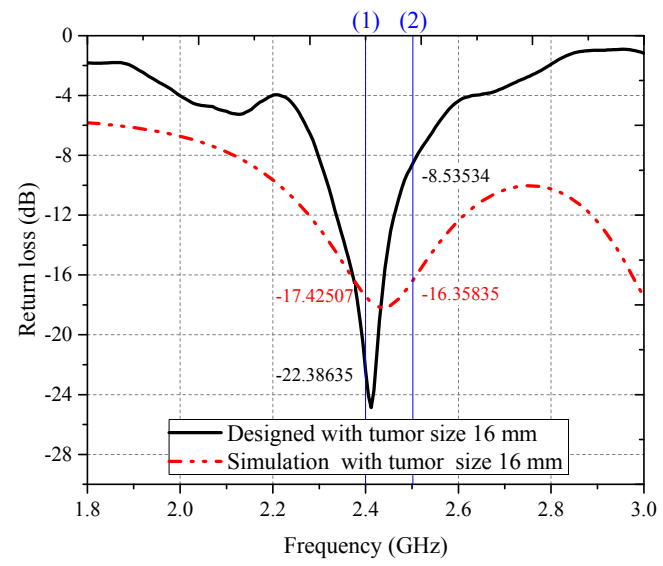

Fig. 9. Return loss in $\mathrm{dB}$ (S11) of the series resonance circuit in simulation and designed with tumor size $16 \mathrm{~mm}$.

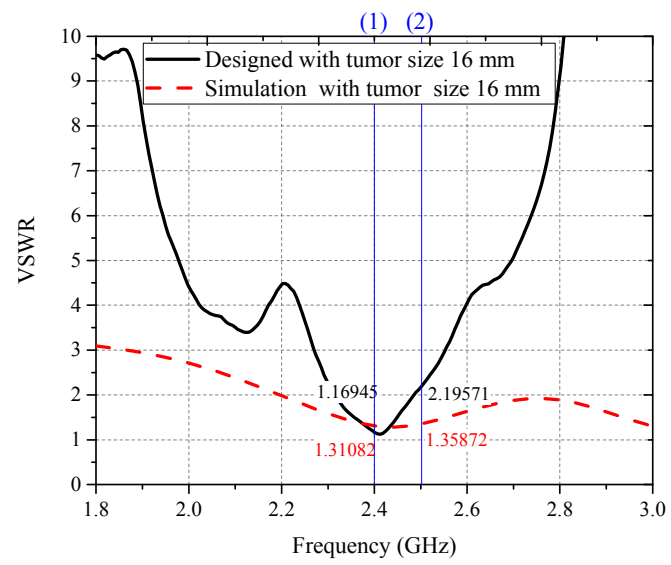

Fig. 10. VSWR of the series resonance circuit in simulation and designed with tumor size $16 \mathrm{~mm}$.

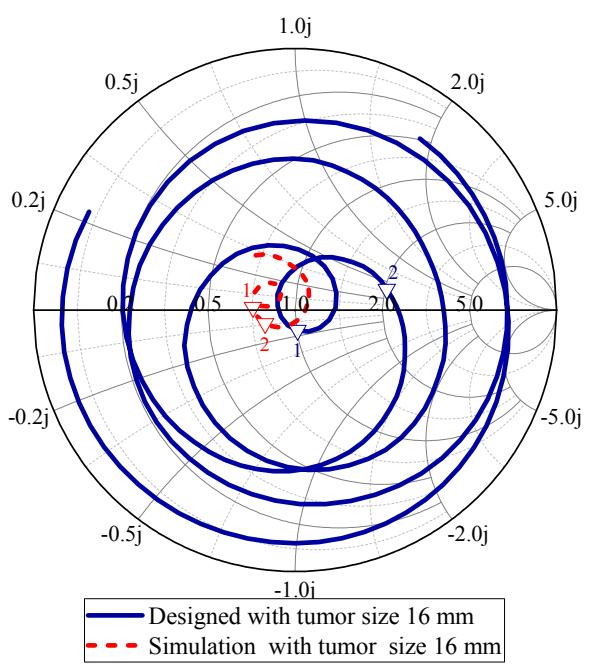

Fig. 11. The impedance of the series resonance circuit in simulation and designed with tumor size $16 \mathrm{~mm}$.

$-23.82 \mathrm{~dB}$. Similarly, Figure 10 demonstrates a VSWR response to $2.41 \mathrm{GHz}$ at 1.12 .

Figure 11 plots the Smith chart for the input impedance of the series resonance circuit for an LC matching network that is normalized to 50. Table 3 compares the 


\begin{tabular}{|c|c|c|c|c|}
\hline \multirow{2}{*}{ Data } & \multicolumn{2}{|c|}{ Simulation } & \multicolumn{2}{c|}{ Measured } \\
\cline { 2 - 5 } & $\begin{array}{c}\mathbf{2 4 0 0} \mathbf{~ M H z} \\
(\mathbf{1})\end{array}$ & $\begin{array}{c}\mathbf{2 5 0 0} \mathbf{~ M H z} \\
(\mathbf{2})\end{array}$ & $\begin{array}{c}\mathbf{2 4 0 0} \mathbf{~ M H z} \\
\text { (1) }\end{array}$ & $\begin{array}{c}\mathbf{2 5 0 0} \mathbf{~ M H z} \\
\text { (2) }\end{array}$ \\
\hline Return loss $(\mathrm{dB})$ & -17.42 & -16.35 & -22.38 & -8.53 \\
\hline VSWR & 1.31 & 1.35 & 1.16 & 2.19 \\
\hline Impedance $(\Omega)$ & $38.19+\mathrm{j} 1.2$ & $38.55-\mathrm{j} 6.89$ & $50.3-\mathrm{j} 7.91$ & $102+\mathrm{j} 18.4$ \\
\hline
\end{tabular}

Tab. 3. Frequency response of series resonance circuit in simulation and designed with tumor size $16 \mathrm{~mm}$.

operating frequency of the resonance circuit and the prediction from the simulation for a $16 \mathrm{~mm}$ tumor for $2400 \mathrm{MHz}$ and $2500 \mathrm{MHz}$.

\subsection{Dielectric Properties of Agar Phantom: Measurement Results}

The dielectric properties of agar phantom and tumor tissue samples were measured using open-ended coaxial dielectric probe kit (N1501A, Keysight Technology) type High Temperature and connected to a vector network analyzer (E5071C, Keysight Technology) to confirm the dielectric property value (see Fig. 12. for setup). The measurement was analyzed using Keysight materials measurement suite 2016 software. The open-ended coaxial probe has been calibrated with air, short-block, and DI water at $24^{\circ} \mathrm{C}$. The calibration frequency was set between $1 \mathrm{GHz}$ and $10 \mathrm{GHz}$. The agar phantom size was $50 \mathrm{~mm}$ in diameter, and the tumor tissue was inside and acted as a dielectric material. The interior tumor is created within the tumor tissue layer with the diameter size of $10 \mathrm{~mm}, 16 \mathrm{~mm}$, or $30 \mathrm{~mm}$. The measurements of the agar phantom and tumor were performed separately. The material must have enough thickness for measuring, maybe thicker than $20 \mathrm{~mm}$. The dielectric properties of agar phantom and tumor tissue samples were subsequently measured.

The composition of agar phantom and tumor tissue recipe given in [29], [34] are listed in Tab. 4. Figure 13 displays the dielectric material created for measurement. The tumor of each size will have the concentration of ingredients in a similar ratio. The compounds are mixed and

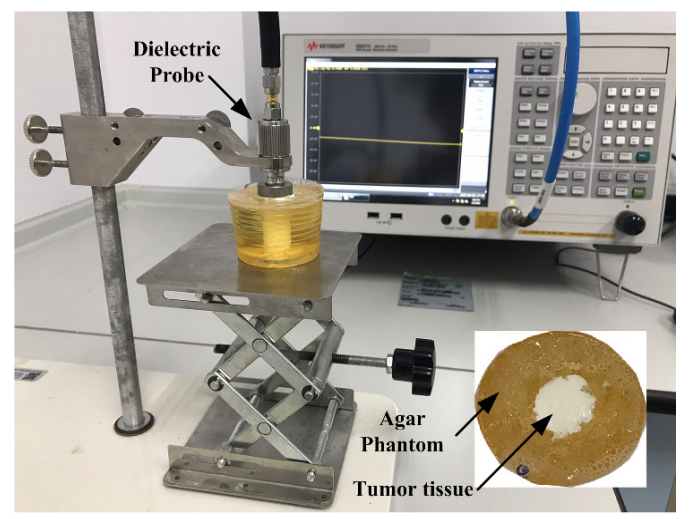

Fig. 12. Measurement setup for dielectric properties of agar phantom and tumor tissue sample.

\begin{tabular}{|c|c|c|c|c|}
\hline Material & $\begin{array}{c}\text { Agar } \\
\text { phantom }\end{array}$ & $\begin{array}{c}\text { Tumor } \\
(\mathbf{1 0} \mathbf{~ m m})\end{array}$ & $\begin{array}{c}\text { Tumor } \\
(\mathbf{1 6} \mathbf{~ m m})\end{array}$ & $\begin{array}{c}\text { Tumor } \\
(\mathbf{3 0} \mathbf{~ m m})\end{array}$ \\
\hline Agar-agar & $30 \mathrm{~g}$ & - & - & - \\
\hline Gelatin & - & $1.5 \mathrm{~g}$ & $4 \mathrm{~g}$ & $15 \mathrm{~g}$ \\
\hline $\mathrm{NaCl}$ & - & $1 \mathrm{~g}$ & $1 \mathrm{~g}$ & $1 \mathrm{~g}$ \\
\hline Corn oil & $1 \mathrm{ml}$ & - & - & - \\
\hline $\begin{array}{c}\text { White color } \\
\text { powder }\end{array}$ & - & $0.5 \mathrm{~g}$ & $0.5 \mathrm{~g}$ & $0.5 \mathrm{~g}$ \\
\hline Deionized water & $40 \mathrm{ml}$ & $1.8 \mathrm{ml}$ & $4.8 \mathrm{ml}$ & $16.9 \mathrm{ml}$ \\
\hline
\end{tabular}

Tab. 4. Composition of agar phantom and tumor tissue.

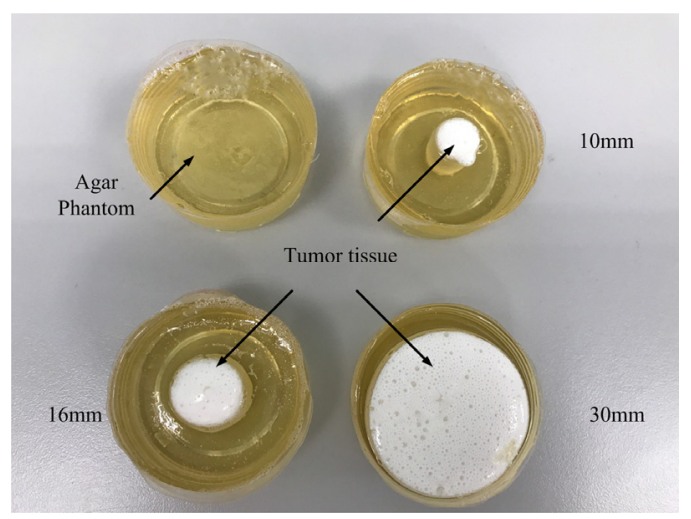

Fig. 13. The agar phantom and tumor size are $10 \mathrm{~mm}, 16 \mathrm{~mm}$, and $30 \mathrm{~mm}$ for experiments with dielectric heating.

heated to $80^{\circ} \mathrm{C}$. Then the mixture was poured into molds of various sizes of the tumor.

Figures 14 and 15 represent dielectric properties results between $1-10 \mathrm{GHz}$ and compared to agar phantom and a tumor tissue sample for each diameter size. From the experimental results, it can be seen that the dielectric constant $\left(\varepsilon^{\prime}\right)$ and loss factor $\left(\varepsilon^{\prime \prime}\right)$ of the agar phantom is significantly different from the tumor tissue. In particular, the tumor tissue has a very different loss factor from agar phantom, as shown in Fig. 14, and Fig. 15, considered in (4), it can be seen that the tumor has higher thermal absorption than agar phantom.

This section measures the dielectric properties of both materials at a constant temperature of $24^{\circ} \mathrm{C}$. The dielectric properties are not stable, depending on the temperature at

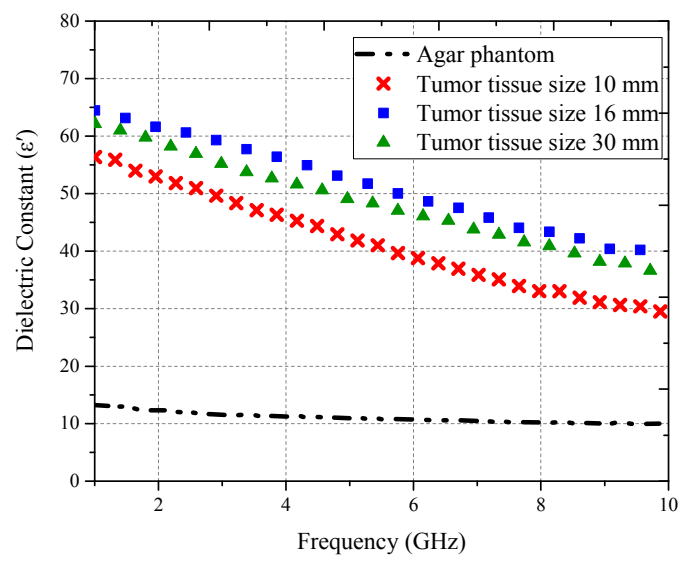

Fig. 14. The dielectric constant of the agar phantom and tumor tissue with the diameter size $10 \mathrm{~mm}, 16 \mathrm{~mm}$, and $30 \mathrm{~mm}$ at $24^{\circ} \mathrm{C}$. 


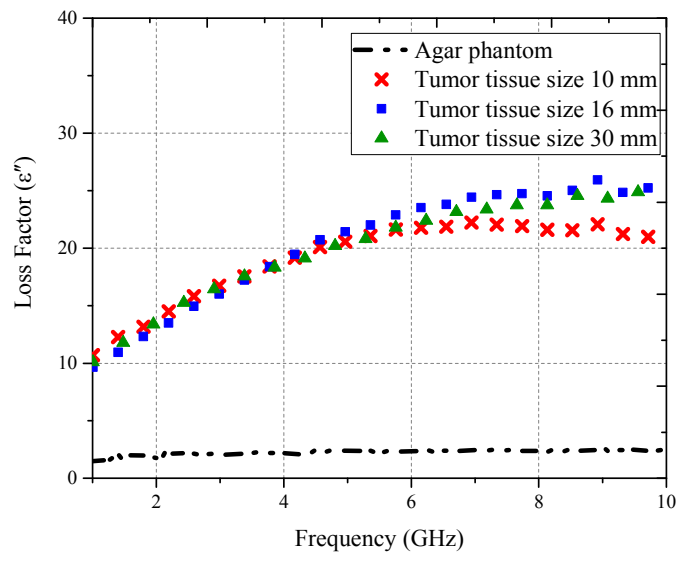

Fig. 15. The losses factor of the agar phantom and tumor tissue with the diameter size $10 \mathrm{~mm}, 16 \mathrm{~mm}$, and $30 \mathrm{~mm}$ at $24^{\circ} \mathrm{C}$.

\begin{tabular}{|c|c|c|}
\hline Tumor size $(\mathrm{mm})$ & Dielectric constant $\left(\varepsilon^{\prime}\right)$ & Loss factor $\left(\varepsilon^{\prime \prime}\right)$ \\
\hline 10 & 51.27 & 15.25 \\
\hline 16 & 60.49 & 14.55 \\
\hline 30 & 57.75 & 15.44 \\
\hline Agar phantom & 12.04 & 2.03 \\
\hline
\end{tabular}

Tab. 5. The dielectric property at $2450 \mathrm{MHz}$ of agar phantom and tumor tissue sample at $24^{\circ} \mathrm{C}$.

that time. Therefore, it is difficult to control the temperature of the dielectric material. In this experiment, the focus is on the differences in dielectric properties of each element that affect microwave heating. Consistent with the theory that the tumor tissue is a better thermal conductor than the surrounding material, the results can show a tendency to generate heat despite fluctuations in the dielectric constant. The dielectric property of agar phantom tumor tissue sample at $2450 \mathrm{MHz}$ is listed in Tab. 5.

\section{The Heating Experiment and Measurement Results}

The experiment of the dielectric heating system consists of a microwave power signal, curved plate applicator with agar phantom. In the analysis, the focus will be on the ability of the electric field of the curved plate to induce heat according to the bio-heat transfer equation for tumors within the body tissue. And the temperature will be investigated that occurs with internal tumors of various sizes and side tissues. Figure 16 shows the construction of the dielectric heating system for breast cancer treatment. Similarly, previous studies have shown theoretical and experimental evidence carried out using an agar phantom. The transferring of the microwave power source will continue $50 \Omega$ transmission line through by the directional coupler power meter Bird (4391A, RF Power Analyst) for measuring the RF power transmitted to the dielectric load.

For the microwave signal generators to be used from the high power semiconductor generators by RF High Power LDMOS Transistor (MRF24300N, Freescale Semiconductor) with a maximum power rating of $300 \mathrm{~W}$. In the

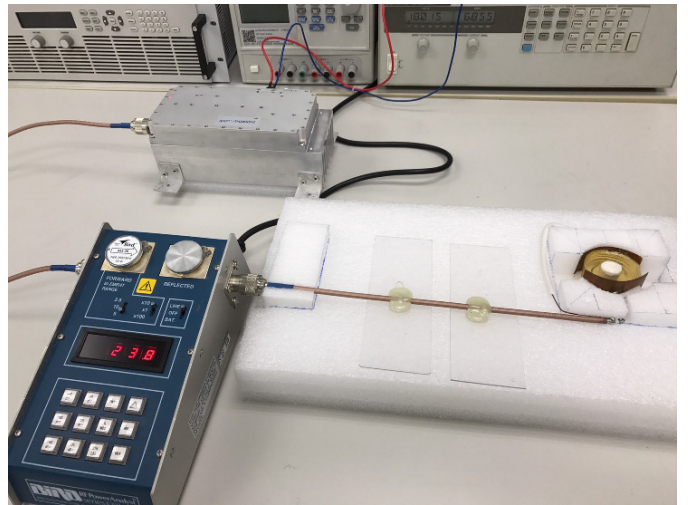

Fig. 16. The microwave dielectric heating system for breast cancer treatment with a curved plate applicator.

\begin{tabular}{|c|c|c|c|c|}
\hline \multirow{2}{*}{ DC input power $(\mathrm{W})$} & \multicolumn{3}{|c|}{ RF power output } & \multirow{2}{*}{ Efficiency (\%) } \\
\cline { 2 - 4 } & $(\mathrm{dBm})$ & $\left(\mathrm{V}_{\mathrm{P}-\mathrm{P}}\right)$ & $(\mathrm{W})$ & \\
\hline 23.5 & 34.4 & 33.2 & 1.8 & 7.66 \\
\hline 43.8 & 37.1 & 45.3 & 4.3 & 9.82 \\
\hline 80.7 & 40.7 & 68.5 & 12.5 & 15.49 \\
\hline 119.8 & 43.6 & 95.7 & 24.0 & 20.02 \\
\hline 147.0 & 45.0 & 127.3 & 32.0 & 21.77 \\
\hline 172.0 & 46.0 & 130.1 & 41.6 & 24.18 \\
\hline
\end{tabular}

Tab. 6. Measurement of DC input power and RF output power efficiency.

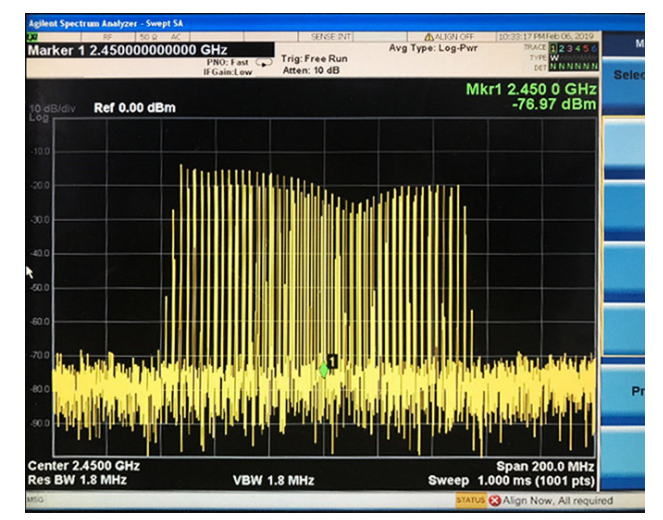

Fig. 17. Microwave signals on channel power at $2450 \mathrm{MHz}$.

experiment, we have examined the efficiency of the microwave output power at various values in Tab. 6. We choose the DC input at $120 \mathrm{~W}$ (input voltage is $18 \mathrm{~V}$ and input current is $6.66 \mathrm{~A}$ ), with the performance was about $20 \%$ to generate RF output power about $24 \mathrm{~W}, 95.72 \mathrm{~V}$ peak to peak in the experiment to induce heat distribution inside the dielectric load of agar phantom. The distance between the plate is equal to $50 \mathrm{~mm}$. The microwave signal has been measured in channel power and connected by power attenuation $30 \mathrm{~dB}$ into the Agilent MXA Signal Analyzer (N9020A). We set the intermediate frequency at $2450 \mathrm{MHz}$ and bandwidth span in the scope of $200 \mathrm{MHz}$, as shown in Fig. 17.

Most electromagnetic waves occur between the plates as a feature in the electric field that is generated. The purpose of the experiment is to investigate the resulting heat from targeting the dielectric tumor material. The energy focus is based on the electric field induction of curved 
plates, which will help to penetrate deep into the body tissue without affecting the neighboring tissue. This method is guided by simulation results and compared with actual experiment results.

In the experimental part, the thermal effect generated by microwave is measured with the $2 \mathrm{D}$ cross-section in $\mathrm{XY}$-plane by the thermal imaging camera, IR camera (U5857A True IR, Keysight Technology). We set the emissivity parameter to 0.98 , background compensation of reflected temperature (RT) $29.3^{\circ} \mathrm{C}$, measured temperature range $22.0-46.5^{\circ} \mathrm{C}$. The experiment was conducted using a tumor size of $10 \mathrm{~mm}, 16 \mathrm{~mm}$, and $30 \mathrm{~mm}$. It was found that after 30, 40, and 60 minutes, respectively, the temperature of the tumor tissue increased from $31^{\circ} \mathrm{C}$ to $42^{\circ} \mathrm{C}$.

Figure 18 represents the experimental results of the temperature distribution surrounding the position of agar phantom. It was found that the heating characteristic is consistent with the theoretical, simulated results. The resulting observation using a thermograph is consistent with the numerical simulation results. The power loss density of the heating model is a part of the electromagnetic wave from the external source excited by $2450 \mathrm{MHz}$ signal because of the power loss density $\left(\mathrm{W} \cdot \mathrm{cm}^{-3}\right)$ of (4) and is directly proportional to the temperature interval of the agar phantom and tumor tissue model. The heat distribution relationship in (2) is likely to occur in tumor samples with power loss and dielectric properties found in (4). However, the side tissue is also affected and heated. The neighboring tissue is heated to $39^{\circ} \mathrm{C}$, which will not affect that tissue. In addition, the heat distribution that occurs is also a function of the size of the tumor tissue. While the maximum temperature of the tumor is at $42^{\circ} \mathrm{C}$, considering the ability to penetrate the tissues by using a curved plate, the results can be seen clearly with smaller tumors are $10 \mathrm{~mm}$ and $16 \mathrm{~mm}$. For tumor size $30 \mathrm{~mm}$, it looks as if the heat is spread over a wide area. However, due to the density of different materials while using the same amount of energy. The time required to test each tumor size was not the same as obtained for the desired temperature. In summary, it is evident that the induction of the electric field can penetrate the internal core with the dielectric principle by using microwave frequency. Therefore, the inner tumor tissue can produce more heat than normal tissues as a result of its dielectric properties and higher loss factor $\left(\varepsilon^{\prime \prime}\right)$.

\section{Discussion}

In the experiment of thermal effects, it is essential to point out that we cannot make a model like a breast shape because the thermal imaging relies on emitting heat from the surface. Similarly, the breast contains other tissues that are not homogeneous. In addition, this experiment does not address the cooling of the blood vessels effect of the circulatory system and merits further study. Also, the size of the different tumors resulted in unequal time to spend to achieve $42^{\circ} \mathrm{C}$ temperatures.

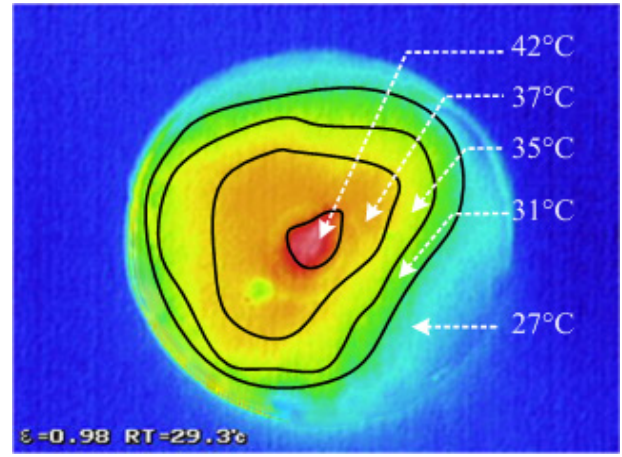

(a)

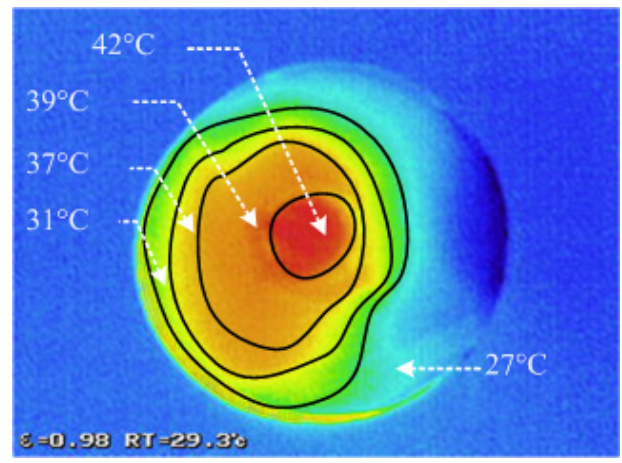

(b)

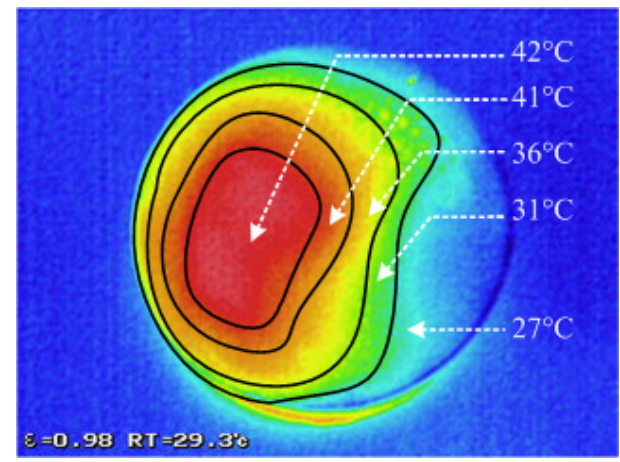

(c)

Fig. 18. Temperature distribution in agar phantom with tumor tissue size: (a) $10 \mathrm{~mm}$ (b) $16 \mathrm{~mm}$ (c) $30 \mathrm{~mm}$.

\section{Conclusion}

This study demonstrates the ability to use dielectric curved plate applicators, excited by a $2450 \mathrm{MHz}$ signal, the return loss $(-22.38 \mathrm{~dB})$. DC input power $120 \mathrm{~W}$ was used to generate the microwave output power of $24 \mathrm{~W}$. This energy was then selectively transferred to a focal area by way of tumor tissues dielectric properties. Thus this study demonstrates the potential application of deep hyperthermia as tumor therapy. It is a novel technique to control an electric field, using curved plate applicators, for focusing on deep tissue areas. The distribution of the loss medium was analyzed. From these investigations, we found that the curved plate applicator yielded the best results because the maximum power loss density is equal to $11.92 \mathrm{~W} \cdot \mathrm{cm}^{-3}$ with tumor $16 \mathrm{~mm}$ in the simulation. The results show that the heating location can be penetrated deep in the agar 
phantom diameter $50 \mathrm{~mm}$ to the inner tumor layer. The experiment value of the maximum temperature distribution in the agar phantom model is approximately $42^{\circ} \mathrm{C}$ for 40 minutes.

\section{Acknowledgments}

This work was supported by Suranaree University of Technology (SUT) and by the Office of the Higher Education under NRU project in Thailand.

\section{References}

[1] ELKAYAL, H. A. ISMAIL, N. E., LOTFY, M. Microwaves for breast cancer treatments. Alexandria Engineering Journal, 2015, vol. 54, no. 4, p. 1105-1113. DOI: 10.1016/j.aej.2015.06.012

[2] LANG, J. ERDMANN, B., SEEBASS, M. Impact of nonlinear heat transfer on temperature control in regional hyperthermia. IEEE Transactions on Biomedical Engineering, 1999, vol. 46, no. 9 , p. 1129-1138. DOI: 10.1109/10.784145

[3] WU, L. CHENG, J., LIU, W., et al. Numerical analysis of electromagnetically induced heating and bioheat transfer for magnetic fluid hyperthermia. IEEE Transactions on Magnetics, 2015, vol. 51, no. 2, p. 1-4. DOI: 10.1109/TMAG.2014.2358268

[4] DŘÍŽĎAL, T., TOGNI, P., VÍŠEK, L., et al. Comparison of constant and temperature dependent blood perfusion in temperature prediction for superficial hyperthermia. Radioengineering, 2010, vol. 19 , no. 2 , p. 281-289. ISSN: $1210-2512$

[5] CONVERSE, M., BOND, E. J., VEEN, B. D., et al. A computational study of ultra-wideband versus narrowband microwave hyperthermia for breast cancer treatment. IEEE Transactions on Microwave Theory and Techniques, 2006, vol. 54, no. 5, p. 2169-2180. DOI: 10.1109/TMTT.2006.872790

[6] FISER, O., MERUNKA, I., VRBA, J. Optimization of microwave hyperthermia applicator system for deep placed tumors treatment in head and neck area. In Progress In Electromagnetics Research Symposium - Spring (PIERS). St. Peterburg (Russia), 2017, p. 1733-1738. DOI: 10.1109/PIERS.2017.8262029

[7] ASILI, M., CHEN, P., HOOD, A. Z., et al. Flexible microwave antenna applicator for chemo-thermotherapy of the breast. IEEE Antennas and Wireless Propagation Letters, 2015, vol. 14, p. 1778-1781. DOI: 10.1109/LAWP.2015.2423655

[8] IERO, D. A. M., CROCCO, L., ISERNIA, T. Thermal and microwave constrained focusing for patient-specific breast cancer hyperthermia: A robustness assessment. IEEE Transactions on Antennas and Propagation, 2014, vol. 62, no. 2, p. 814-821. DOI: 10.1109/TAP.2013.2293336

[9] STANG, J., HAYNES, M., CARSON, P., et al. A preclinical system prototype for focused microwave thermal therapy of the breast. IEEE Transactions on Biomedical Engineering, 2012, vol. 59, no. 9, p. 2431-2438. DOI: 10.1109/TBME.2012.2199492

[10] CORREIA, D., PETRA KOK, H., DE GREEF, M., et al. Body conformal antennas for superficial hyperthermia: The impact of bending contact flexible microstrip applicators on their electromagnetic behavior. IEEE Transactions on Biomedical Engineering, 2009, vol. 56, no. 12, p. 2917-2926. DOI: 10.1109/TBME.2009.2029081

[11] GUPTA, R. C., SINGH, S. P. Elliptically bent slotted waveguide conformal focused array for hyperthermia treatment of tumors in curved region of human body. Progress In Electromagnetics Research, 2006, vol. 62, p. 107-125. DOI: 10.2528/PIER06012801

[12] NGUYEN, P. T., ABBOSH, A., CROZIER, S. Three-dimensional microwave hyperthermia for breast cancer treatment in a realistic environment using particle swarm optimization. IEEE Transactions on Biomedical Engineering, 2017, vol. 64, no. 6, p. 1335-1344. DOI: 10.1109/TBME.2016.2602233

[13] NGUYEN, P. T., ABBOSH, A., CROZIER, S. Microwave hyperthermia for breast cancer treatment using electromagnetic and thermal focusing tested on realistic breast models and antenna arrays. IEEE Transactions on Antennas and Propagation, 2015, vol. 63, no. 10, p. 4426-4434. DOI: 10.1109/TAP.2015.2463681

[14] BELLIZZI, G., BUCCI, O. M. Magnetic nanoparticle-guided blind focusing of the electric field for microwave hyperthermia. IEEE Access, 2017, vol. 5, p. 17246-17257. DOI: 10.1109/ACCESS.2017.2740967

[15] CONVERSE, M., BOND, E. J., Hagness, S. C., et al. Ultrawideband microwave space-time beamforming for hyperthermia treatment of breast cancer: A computational feasibility study. IEEE Transactions on Microwave Theory and Techniques, 2004, vol. 52, no. 8, p. 1876-1889. DOI: 10.1109/TMTT.2004.832012

[16] PETRA KOK, H., DE GREEF, M., VAN WIERINGEN, N., et al. Comparison of two different $70 \mathrm{MHz}$ applicators for large extremity lesions: Simulation and application. International Journal of Hyperthermia, 2010, vol. 26, no. 4, p. 376-388. DOI: $10.3109 / 02656730903521383$

[17] VAN STAM, G., PETRA KOK, H., HUlShOF, M. C. C. M., et al. A flexible $70 \mathrm{MHz}$ phase-controlled double waveguide system for hyperthermia treatment of superficial tumors with deep infiltration. International Journal of Hyperthermia, 2017, vol. 33, no. 7, p. 796-809. DOI: 10.1080/02656736.2017.1313460

[18] PETRA KOK, H., CREZEE, J. A comparison of the heating characteristics of capacitive and radiative superficial hyperthermia. International Journal of Hyperthermia, 2017, vol. 33, no. 4, p. 378-386. DOI: 10.1080/02656736.2016.1268726

[19] VAN WIERINGEN, N., WIERSMA, J., ZUM VÖRDE SIVE VÖRDING, P., et al. Characteristics and performance evaluation of the capacitive contact flexible microstrip applicator operating at $70 \mathrm{MHz}$ for external hyperthermia. International Journal of Hyperthermia, 2009, vol. 25, no. 7, p. 542-553. DOI: $10.3109 / 02656730903061591$

[20] VAN DE KAMER, J. B., VAN WIERINGEN, N., DE LEEUW, A. A. C., et al. The significance of accurate dielectric tissue data for hyperthermia treatment planning. International Journal of Hyperthermia, 2001, vol. 17 , no. 2, p. 123-142. DOI: $10.1080 / 02656730150502297$

[21] VRBA, D., VRBA, J. Novel applicators for local microwave hyperthermia based on zeroth-order mode resonator metamaterial. International Journal of Antennas and Propagation, 2014, vol. 2014, p. 1-7. DOI: $10.1155 / 2014 / 631398$

[22] VRBA, D., VRBA, J., RODRIGUES, D. B., et al. Numerical investigation of novel microwave applicators based on zero-order mode resonance for hyperthermia treatment of cancer. Journal of the Franklin Institute, 2017, vol. 354, no. 18, p. 8734-8746. DOI: 10.1016/j.jfranklin.2016.10.044

[23] VRBA, D., RODRIGUES, D., VRBA, J. (JR.), et al. Metamaterial antenna arrays for improved uniformity of microwave hyperthermia treatments. Progress In Electromagnetics Research, 2016, vol. 156, p. 1-12. DOI: 10.2528/PIER16012702

[24] MARTEllosio, A., PASIAN, M., BOZZI, M., et al. Dielectric properties characterization from 0.5 to $50 \mathrm{GHz}$ of breast cancer tissues. IEEE Transactions on Microwave Theory and Techniques, 2017, vol. 65, no. 3, p. 998-1011. DOI: 10.1109/TMTT.2016.2631162 
[25] SUGitAnI, T., KUBOTA, S.-I., KUROKI, S.-I., et al. Complex permittivities of breast tumor tissues obtained from cancer surgeries. Applied Physics Letters, 2014, vol. 104, no. 25, p. 1-5. DOI: $10.1063 / 1.4885087$

[26] JIAO, S., JOHNSON, J. A., TANG, J., et al. Dielectric properties of cowpea weevil, black-eyed peas and mung beans with respect to the development of radio frequency heat treatments. Biosystems Engineering, 2011, vol. 108, no. 3, p. 280-291. DOI: 10.1016/j.biosystemseng.2010.12.010

[27] WANG, S., TANG, J., CAVALIERI, R. P., et al. Differential heating of insects in dried nuts and fruits associated with radio frequency and microwave treatments. Transactions of the American Society of Agricultural and Biological Engineers, 2003, vol. 46, no. 4, p. 1175-1182. DOI: 10.13031/2013.13941

[28] NELSON, S. O., CHARITY, L. F. Frequency dependence of energy absorption by insects and grain in electric fields. Transactions of the American Society of Agricultural and Biological Engineers, 1972, vol. 15, no. 6, p. 1099-1102. DOI: $10.13031 / 2013.38079$

[29] NGUYEN, P. T., ABBOSH, A., CROZIER, S. Thermo-dielectric breast phantom for experimental studies of microwave hyperthermia. IEEE Antennas and Wireless Propagation Letters, 2016, vol. 15, p. 476-479. DOI: 10.1109/LAWP.2015.2453432

[30] ZASTROW, E., DAVIS, S. K., LAZEBNIK, M., et al Development of anatomically realistic numerical breast phantoms with accurate dielectric properties for modeling microwave interactions with the human breast. IEEE Transactions on Biomedical Engineering, 2008, vol. 55, no. 12, p. 2792-2800. DOI: 10.1109/TBME.2008.2002130

[31] ARUNACHALAM, K., UDPA, S. S., UDPA, L. Microwave breast cancer hyperthermia using deformable mirror. In IEEE Antennas and Propagation Society International Symposium. Albuquerque (USA), 2006, p. 2191-2194. DOI: 10.1109/APS.2006.1711022

[32] NGUYEN, P. T., ABBOSH, A., CROZIER, S. 3-D focused microwave hyperthermia for breast cancer treatment with experimental validation. IEEE Transactions on Antennas and Propagation, 2017, vol. 65, no. 7, p. 3489-3500. DOI: 10.1109/TAP.2017.2700164

[33] KANAI, Y., TSUKAMOTO, T., SAITOH, Y., et al. Analysis of a hyperthermic treatment using a reentrant resonant cavity applicator for a heterogeneous model with blood flow. IEEE Transactions on Magnetics, 1997, vol. 33, no. 2, p. 2175-2178. DOI: $10.1109 / 20.582763$
[34] POOMPAVAI, S., GOWRI SREE, V. Dielectric property measurement of breast-tumor phantom model under pulsed electric field treatment. IEEE Transactions on Radiation and Plasma Medical Sciences, 2018, vol. 2, no. 6, p. 608-617. DOI: 10.1109/TRPMS.2018.2868818

\section{About the Authors ...}

Supawat KOTCHAPRADIT (corresponding author) received the B.Eng. (1'Hons) in Electronic Engineering (2013), from Suranaree University of Technology. At present he has been studying a Ph.D. degree in Electronic Engineering since 2014, Suranaree University of Technology, Thailand. Research interests include power electronics, microwave circuit and RF circuit design.

Chanchai THONGSOPA received the D.Eng. (Electrical Engineering), King Mongkut's Institute of Technology Ladkrabang (KMITL), Thailand in 2002. Lecturer, School of and Electronic Engineering. At present Associate Professor, School of Electronic Engineering, Suranaree University of Technology, Thailand. Experiences \& Expert are RF circuit design, active antenna, microwave heating application.

Thanaset THOSDEEKORAPHAT received the Ph.D. in Telecommunication Engineering (2012), Suranaree University of Technology, Thailand. At present Lecturer, School of Electronic Engineering, Suranaree University of Technology, Thailand. Research interests include hyperthermia inductive heating, magnetic shielding system, RF and microwave circuit design, microwave heating, antenna. In addition, as a reviewer of the International Journal of Antennas and Propagation. At present Assistant Professor in Electronics Engineering Head, School of Electronics Engineering. 